\title{
RARE CASE OF SUBCUTANEOUS GRANULAR CELL TUMOUR - A CASE REPORT
}

\author{
M. Sridevi ${ }^{1}$, Anita Samraj², Ganthimathy Sekar³, C. R. V Narasimhalu ${ }^{4}$
}

\section{HOW TO CITE THIS ARTICLE:}

M. Sridevi, Anita Samraj, Ganthimathy Sekar, C. R. V Narasimhalu. "Rare Case of Subcutaneous Granular Cell Tumor - A Case Report". Journal of Evolution of Medical and Dental Sciences 2014; Vol. 3, Issue 13, March 31; Page: 3520-3523, DOI: $10.14260 /$ jemds/2014/2314

ABSTRACT: INTRODUCTION: Granular cell tumor, also known as Abrikossoff's tumor, is a rare benign tumor of neural origin, which can arise at any part of the body; however the tongue (30\%) is the most commonly affected site. Its clinical behavior is usually benign although malignant and multifocal forms are also known to occur. CASE REPORT: A case of granular cell tumor in a 33 year old female who presented with a firm hyperpigmented nodule on the lateral aspect of the left upper arm. CONCLUSION: This case is quite rare: only a few cases were presented in literature with hyperpigmentation.

KEYWORDS: Granular cell tumor, Abrikossoff's tumor, hyperpigmented nodule.

INTRODUCTION: Granular cell tumor or Abrikossoff's tumor ${ }^{1}$ is an uncommon soft tissue neoplasm. These tumors primarily affect adults but may be found in children rarely. They are more common in females and often develop between the fourth and sixth decades of life. ${ }^{2}$ Granular cell tumors can affect all parts of the body; however, the head and neck areas are most commonly affected.

CASE REPORT: A 33 year old female presented with a firm hyperpigmented nodule on the lateral aspect of the left upper arm. The swelling was of 4 months duration and she also complained of slight pain. On examination the nodule was hyperpigmented and measured about $3 \mathrm{~cm}$ in diameter. (Figure: 1). Fine Needle Aspiration Cytology showed clusters of round cells with moderate cytoplasm and regular nucleus with prominent nucleoli, some showing nuclear inclusions (Figure: 2, 3). A provisional diagnosis of? Melanoma? Skin adnexal tumor was given. Excision biopsy of the lesion was advised.

The excision biopsy specimen consisted of a skin covered soft tissue mass measuring $4 \times 3 \times 2$ $\mathrm{cm}$. The external surface showed a pigmented nodule measuring $3 \mathrm{~cm}$ in diameter. On sectioning, there was a grey white firm nodule extending into the dermis for about $1 \mathrm{~cm}$ in depth. Histological examination showed nests of polygonal cells with abundant granular cytoplasm, distinct cell membrane and centrally placed round uniformly stained nucleus separated by delicate fibrous tissue (Figures: 4). In other areas the nuclei were vesicular with prominent nucleolus. There was no cytological pleomorphism or mitosis. The cytoplasmic granules were Periodic Acid Schiff (PAS) positive (Figure: 5). Excision margins were free of the tumor. Immunohistochemistry showed positivity with S-100 and (Figures: 6). The case was reported as Granular cell tumor.

DISCUSSION: Granular cell tumor (GCT) is a rare neoplasm which accounts for about approximately $0.5 \%$ of all soft tissue tumors Incidence of occurrence in the extremities are $13 \%$ and in the arm is $6 \%$. In the skin or subcutaneous tissue it is $30-40 \%$.(2) Other sites include esophagus, stomach, appendix, larynx, bronchus, pituitary gland, uvea and skeletal muscle ${ }^{3}$. These tumors are usually 
solitary but in 10 to $15 \%$ of cases, they may occur as multiple nodules. GCTs of the skin are well circumscribed, raised, firm and nodular. Tenderness and pruritus may be present in some tumors. They range from 0.5 to $3 \mathrm{~cm}$ in diameter and the overlying skin may be normal, verrucous ${ }^{3}$ or hyperpigmented. When they are pigmented they can be misdiagnosed clinically as malignant melanoma, bednar tumor, mycosis fungoides and neurothekeoma. ${ }^{4}$

Cytological findings in Granular cell tumors are syncytial clusters of cells with small round or oval nuclei with bland chromatin and small prominent nucleoli. The cytoplasm is abundant, granular and eosinophilic. As the cytoplasm is fragile, the background shows numerous stripped nuclei.5, 6, and 7

Histologically, these tumors are non-encapsulated and the overlying epithelium may show secondary epithelial hyperplasia. ${ }^{8}$ The tumor is composed of nests or ribbons of large polygonal cells with distinct cell membrane separated by delicate fibrous connective tissue. The cytoplasm is eosinophilic and granular (PAS positive granules). Nuclei range from small and dark to large with vesicular chromatin and prominent nucleolus. ${ }^{2}$ An occasional nucleus may contain a cytoplasmic inclusion. ${ }^{3}$

The origin of granular cell tumors is uncertain. Initially these tumors were thought to arise from skeletal muscle because of their cytological resemblance to myocytes and were called as granular cell myoblastoma. ${ }^{1}$ Granular cell tumors are strongly positive for the panmacrophage antigen CD68 as their granules are lysosomal in nature. Based on the evidence that CD68 reacts positively with schwannomas and granular cell tumors and that granular cell tumors stain for S-100 protein, these tumors are thought to originate from Schwann's cells. ${ }^{2,1}{ }^{\text {and } 9}$ Hence they are referred to as granular cell nerve sheath tumor and granular cell schwannoma. ${ }^{9}$

These tumors are slow growing. However recurrences may occur after incomplete excision. Malignancy is rare and comprises only $2 \%$ of all granular cell tumors. The features of malignancy are large size combined with histologic findings of necrosis, increased mitotic figures, cellular and nuclear pleomorphism and spindling of tumor cells. ${ }^{1}$

CONCLUSION: In this case the granular cell tumor presented as a hyperpigmented nodule, resulting in a clinical diagnosis of a melanocytic lesion. Hence this entity should also be thought of in the differential diagnosis of hyperpigmented nodular skin lesions.

\section{REFERENCES:}

1. Giovanni Francesco Marangi, Vito Toto, Igor Poccia, Pierluigi Gigliofiorito, Beniamo Brunetti and Paolo Persichetti . Multiple localization of granular cell tumour: a case report. Cases Journal 2009, 2:8751 doi:10.4076/1757-1626-2-8751

2. Weiss SW, Goldblum JR. Granular cell tumor. In Enzinger and Weiss's soft tissue tumors, 4th edition. Mosby, 2001, 1178-88.

3. David E, Elder. Granular cell tumor. In Levers Histopathology of the skin, 10th edition. Rosalie Elenitsas, Bernett L. Johnson Jr, George F. Murphy, Xiaowei Xu, 2008, 1130 - 1132.

4. S Edwards and K Blessing. Problematic pigmented lesions: approach to diagnosis. J Clin Pathol 2000; 53:409-418 doi:10.1136/jcp.53.6.409

5. Svante R. Orell, Max N-I Walters, Gregory F. Sterrett, Darrel Whitaker. Granular cell tumour. In Fine Needle Aspiration Cytology, 4th edition. Elsevier Churchill Livingstone, 2005, 426 
6. Leopold G. Koss, Myron R. Melamed. Granular cell tumour. In Koss' Diagnostic cytology and its histologic basis, $5^{\text {th }}$ edition. Lippincott Williams \& Wilkins, 2006, 1099-1100, volume II.

7. Avninder Singh, Manav Sawhney, and Sushruta Das. Granular cell tumors of skin diagnosed on fine needle aspiration cytology. Indian J Dermatol. 2012 Jul-Aug; 57(4): 330331.PMCID: PMC3401863doi: 10.4103/0019-5154.97690

8. Rapini Ronald P, Bolognia Jean L, Jorizzo Joseph L. (2007).Dermatology: 2-Volume Set. St. Louis: Mosby. pp.1796, 1804.

9. Mamina Bhoi, Sarvesh. B. M, B. Krishnaswamy, P. Viswanathan, R. Ramesh. "Unique case of granular cell tumour of skin with bilateral gynaecomastia in a teenager with multiple café au lait spots". Journal of Evolution of Medical and Dental Sciences 2013; Vol2, Issue 27, July 8; Page: 4861-4871.

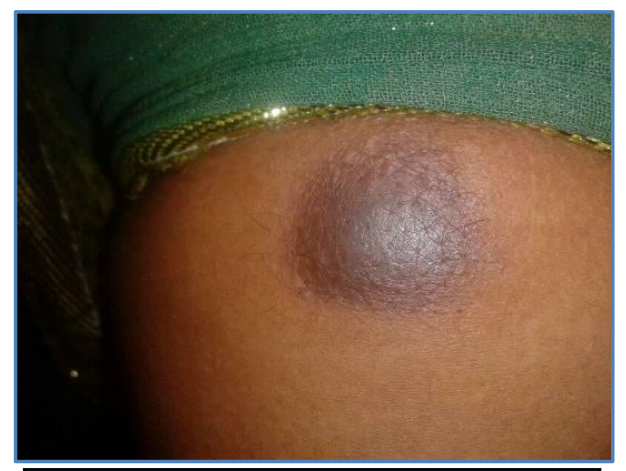

Fig. 1: Hyperpigment Nodule

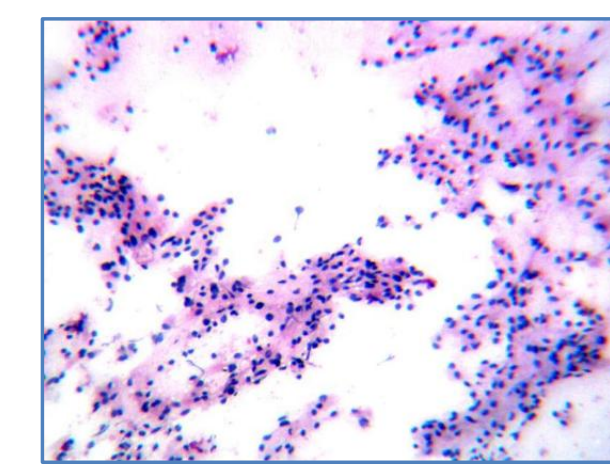

Fig. 2: FNAC showing clusters of round cells with moderate cytoplasm and regular nucleus (H\&E, 100X)

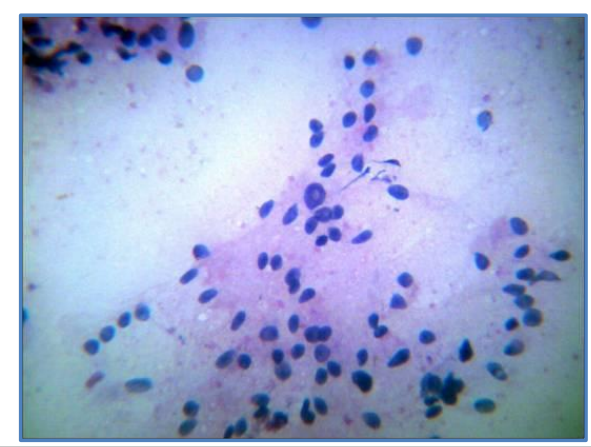

Fig. 3: FNAC showing round cells with nuclear inclusions (H\&E, 400X) 


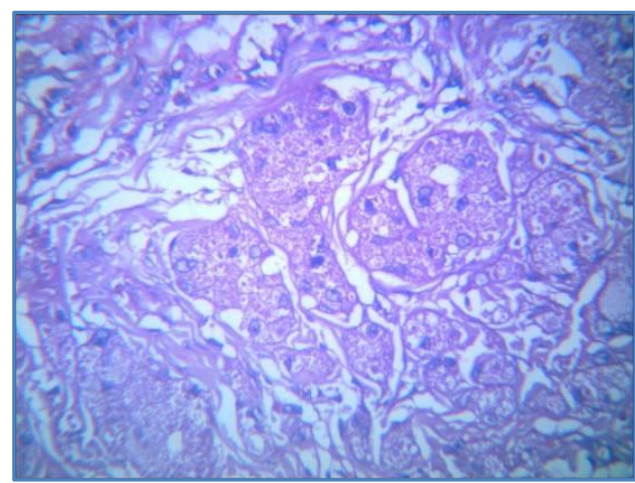

Fig. 4: Nests of polygonal cells with abundant granular cytoplasm, distinct cell membrane and centrally placed round nucleus separated by delicate fibrous tissue (H\&E, 100X)

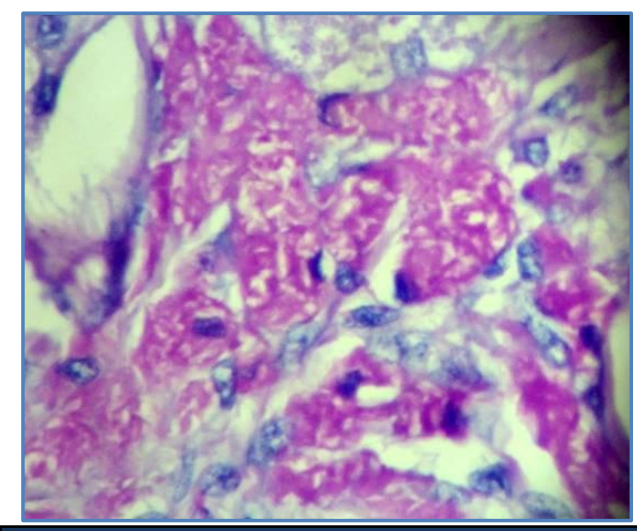

Fig. 5: PAS positive granules $(1000 \mathrm{X})$

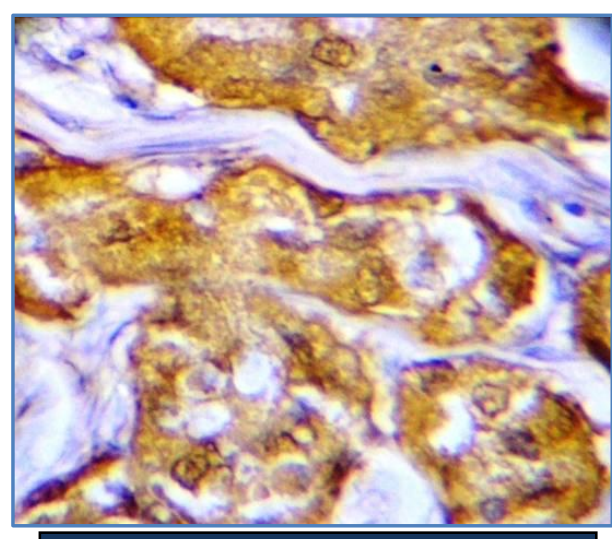

Fig. 6: S-100 positivity $(1000 \mathrm{X})$

\section{AUTHORS: \\ 1. M. Sridevi \\ 2. Anita Samraj \\ 3. Ganthimathy Sekar \\ 4. C. R. V Narasimhalu}

\section{PARTICULARS OF CONTRIBUTORS:}

1. Assistant Professor, Department of Pathology, Saveetha Medical College \& Hospital.

2. Associate Professor, Department of Surgery, Saveetha Medical College \& Hospital.

3. Professor, Department of Pathology, Saveetha Medical College \& Hospital.

4. Associate Professor, Department of Dermatology, Saveetha Medical College \& Hospital.

\section{NAME ADDRESS EMAIL ID OF THE CORRESPONDING AUTHOR:}

Dr. Anita Samraj, Associate Professor, Department of Surgery, B9, Staff Quarters, Saveetha Medical College Campus, Saveetha Nagar, Thandalam, Kancheepuram District - 602105. E-mail: anitaamarsamraj@gmail.com

Date of Submission: 10/02/2014. Date of Peer Review: 11/02/2014. Date of Acceptance: 18/02/2014. Date of Publishing: 29/03/2014. 